\title{
Potential efficacy of vaccines and other immunotherapeutic strategies for treatment of an intracerebral tumor
}

\author{
Terry Lichtor* \\ Department of Neurological Surgery, Rush University Medical Center, USA
}

Although technical advances have resulted in marked improvements in the ability to diagnose and surgically treat primary brain tumors, the incidence and mortality rates of these tumors are increasing [1]. The present standard treatment modalities following surgical resection including cranial irradiation and systemic or local chemotherapy each have serious adverse side effects. The few longterm survivors are inevitably left with cognitive deficits and other disabilities [2,3]. The difficulties in treating malignant gliomas can be attributed to several factors. Glial tumors are inherently resistant to radiation and standard cytotoxic chemotherapies $[4,5]$. The existence of blood-brain and blood-tumor barriers impedes drug delivery to the tumor and adjacent brain infiltrated with tumor. The low therapeutic index between tumor sensitivity and toxicity to normal brain severely limits the ability to systemically deliver therapeutic doses of drugs to the tumor.

Antigenic differences between normal and malignant cells of the cancer patient form the rationale for clinical immunotherapeutic strategies. Because the antigenic phenotype of neoplastic cells varies widely among different cells within the same malignant cellpopulation, immunization with a vaccine that stimulates immunity to the broad array of tumor antigens expressed by the cancer cells is likely to be more efficacious than immunization with a vaccine for a single antigen. A vaccine prepared by transfer of DNA from the tumor into a highly immunogenic cell line can encompass the array of tumor antigens that characterize the patient's neoplasm. Poorly immunogenic tumor antigens, characteristic of malignant cells, can become strongly antigenic if they are expressed by highly immunogenic cells. The enhanced immunotherapeutic properties of a vaccine prepared by transfer of a cDNA expression library derived from breast cancer cells into a mouse fibroblast cell line appears to have great potential in treatment of intracerebral tumors [6]. As the transferred cDNA integrates spontaneously into the genome of the recipient cells, replicates as the cells divide and is expressed, the vaccine could be prepared from small amounts of tumor tissue, enabling treatment at an early stage of the disease, when tumor tissue is available in only limited amounts and the tumor is most susceptible to immune-based therapy. However, like other cellular tumor vaccines, only a small proportion of the transfected cell population was expected to have incorporated cDNA fragments that specified tumor antigens. A novel enrichment strategy has also been developed to increase the proportion of immunotherapeutic cells in the vaccine [7]. Finally, regulatory T cells $\left(\mathrm{CD} 4{ }^{+} \mathrm{CD} 25^{+} \mathrm{Fox} \mathrm{p}^{+}\right.$-positive) were found to be relatively deficient in the spleen cells from the tumor-bearing mice injected intracerebrally with the enriched vaccine.

A number of other different strategies have been attempted to develop vaccines that generate enhanced anti-tumor immune responses in mice and patients with intracerebral neoplasms involving the central nervous system. Vaccines have been prepared by "feeding" antigen presenting (dendritic) cells apoptotic bodies from tumor cells or tumor cell lysates. Introduction of tumor cell-derived RNA into dendritic cells is another approach which has been developed. Immunization with dendritic cells "fed" derivatives of tumor cells or transfected with tumor-RNA can result in the induction of immune responses against the broad array of tumor antigens expressed by the population of malignant cells including tumors of neuroectodermal origin $[8,9]$. In patients, immunization with autologous dendritic cells transfected with mRNA from malignant glioma elicited tumorspecific $\mathrm{CD}^{+}$cytotoxic T-lymphocyte (CTL) responses against the patient's malignant cells [10]. Novel and more specific targets such as glioma stem-like cells have been shown to increase the success of dendritic cell immunotherapy [11]. Although results of dendritic cell immunotherapy have demonstrated promise in animal models, clinical trials have demonstrated relatively short benefits or limited to a minority of treated patients [12].

Other tumor vaccination strategies have been used including modification of neoplastic cells to generate anti-tumor immune responses. Immunization with tumor cells modified to secrete immune-augmenting cytokines such as IL-2 and GM-CSF has resulted in the development of generalized MHC-restricted anti-tumor immune responses in animal models [13-21]. Selective tumor regression was observed in experimental animals receiving immunotherapy alone, in support of the potential of this type of treatment for patients with malignant disease. The effects of cytokine expression by central nervous system tumors (CNS) were examined initially using glioma cells that were engineered to secrete IL-4 [21]. In these studies, it was demonstrated that IL- 4 transduced glioma cells resulted in the development of anti-tumor immune responses. Delivery of an IFN- $\beta$ expression plasmid by cationic liposomes to the CNS tumor site was also found to induce significant anti-CNS tumor immunity in preclinical models [22]. Use of a high-titer adenoviral vector encoding IL-12 is another strategy that was reported to induce anti-tumor responses in a glioma model [23]. Epidermal growth factor variant III is a common alteration of the epidermal growth factor receptor found in human tumors, and a peptide vaccine has now proceeded to phase 1 and 2 clinical trials in patients bearing a malignant glioma with the ability of inducing potent $\mathrm{T}$ - and $\mathrm{B}$-cell immunity and prolongation

Correspondence to: Terry Lichtor, Department of Neurological Surgery, Rush University Medical Center, USA, E-mail: Terry_Lichtor@rush.edu

Received: August 06, 2016; Accepted: August 16, 2016; Published: August 19, 2016 
of survival $[24,25]$. To specifically target natural killer cell activity against gliomas, cells capable of expanding human natural killer cells (NK-92/5.28.z cells which express an ERbB2-specific chimeric antigen receptor) have been shown to significantly prolong survival of mice with an intracranial tumor [26]. Semi-allogeneic vaccines produced by fusion of a tumor line with an allogeneic cell line have been shown to prolong survival in mice with an intracranial tumor when the irradiated cells were injected subcutaneously [27].

Tumor cells may evade immune responses by losing expression of antigens or major histocompatiblity complex (MHC) molecules or by producing immunosuppressive cytokines. In addition, $\mathrm{T}$ cells that recognize self-antigens may differentiate into suppressor or regulatory cells, which inhibit the activation and/or functions of effector cells. Primary brain tumors along with tumors metastatic to the brain have been found to express a variety of immunosuppressive mechanisms that may be targeted for therapeutic gain $[28,29]$. The inhibitory effects of suppressor cells may be mediated by cytokines; in particular interleukin-10 and TGF- $\beta$ are two examples of such cytokines. Successful methods to induce immunity to TAAs along with the use of checkpoint inhibitors $[29,30]$, which target immune cell receptors that interfere with the activation of immune effector cells, could lead to tumor cell destruction and prolong the survival of cancer patients.

The ultimate goal of cancer therapy is the elimination of every remaining tumor cell from the patient. It is unlikely that a single form of therapy is capable of achieving this goal. However, immunotherapy in combination with surgery, radiation therapy and chemotherapy will likely find a place as a new and important means of treatment for patients with brain tumors. Further research involving the development of immunotherapeutic strategies that optimize immunogenicity and target tumor adaptive immunosuppressive factors in patients with brain tumors is needed.

\section{References}

1. Ries LAG, Kosary CL, Hankey BF, Miller BA, Edwards BK (1988) Cancer statistics review. National Cancer Institute 1973-1995. [Crossref]

2. Imperato JP, Paleologos NA, Vick NA (1990) Effects of treatment on long-term survivors with malignant astrocytomas. Ann Neurol 28: 818-822. [Crossref]

3. Heimans JJ, Taphoorn MJ (2002) Impact of brain tumour treatment on quality of life. $J$ Neurol 249: 955-960. [Crossref]

4. Belanich M, Randall T, Pastor MA, Kibitel JT, Alas LG, et al. (1996) Intracellular localization and intercellular heterogeneity of the human DNA repair protein $\mathrm{O}(6)$ methylguanine-DNA methyltransferase. Cancer Chemother Pharmacol 37: 547-555. [Crossref]

5. Hotta T, Saito Y, Fujita H, Mikami T, Kurisu K, et al (1994) O6-alkylguanine-DNA alkyltransferase activity of human malignant glioma and its clinical implications. $J$ Neurooncol 21: 135-140. [Crossref]

6. Lichtor T, Glick RP, Lin H, O-Sullivan I, Cohen EP (2005) Intratumoral injection of IL-secreting syngeneic/allogeneic fibroblasts transfected with DNA from breast cancer cells prolongs the survival of mice with intracerebral breast cancer. Cancer Gene Ther 12: 708-714. [Crossref]

7. Lichtor T, Glick RP, Feldman LA, Osawa G, Hardman J (2008) Enhanced immunity to intracerebral breast cancer in mice immunized with a cDNA-based vaccine enriched for immunotherapeutic cells. Journal of Immunotherapy 31: 18-27. [Crossref]

8. Insug $\mathrm{O}, \mathrm{Ku} \mathrm{G}$, Ertl HC, Blaszczyk-Thurin M (2002) A dendritic cell vaccine induces protective immunity to intracranial growth of glioma. Anticancer Res 22: 613-621. [Crossref]

9. Rosenberg SA, Yang JC, Restifo NP (2004) Cancer immunotherapy: moving beyond current vaccines. Nat Med 10: 909-915. [Crossref]

10. Kobayashi T, Yamanaka R, Homma J, Tsuchiya N, Yajima N, et al. (2003) Tumor mRNA-loaded dendritic cells elicit tumor-specific CD8+ cytotoxic T cells in patients with malignant glioma. Cancer Immunol Immunother 52: 632-637. [Crossref]
11. Finocchiaro G, Pellegatta S (2016) Immunotherapy with dendritic cells loaded with glioblastoma stem cells: from preclinical to clinical studies. Cancer Immunol Immunother 65: 101-109. [Crossref]

12. Reardon DA, Gilbert MR, Wick W, Liau L (2015) Immunotherapy for neuro-oncology: the critical rationale for combinatorial therapy. Neuro Oncol 17 Suppl 7: vii32-32vii40. [Crossref]

13. Gansbacher B, Bannerji R, Daniels B, Zier K, Cronin K, et al. (1990) Retroviral vectormediated gamma-interferon gene transfer into tumor cells generates potent and long lasting antitumor immunity. Cancer Res 50: 7820-7825. [Crossref]

14. Colombo MP, Ferrari G, Stoppacciaro A, Parenza M, Rodolfo M, et al. (1991) Granulocyte colony-stimulating factor gene transfer suppressed tumorigenicity of a murine adenocarcinoma in vivo. J Exp Med 173: 889-897. [Crossref]

15. Golumbek PT, Lazenby AJ, Levitsky HI, Jaffee LM, Karasuyama H, et al (1991) Treatment of established renal cancer by tumor cells engineered to secrete interleukin-4. Science 254: 713-716. [Crossref]

16. Mullen CA, Coale MM, Levy AT, Stetler-Stevenson WG, Liotta LA, et al. (1992) Fibrosarcoma cells transduced with the IL-6 gene exhibit reduced tumorigenicity, increased immunogenicity, and decreased metastatic potential. Cancer Res 52: 60206024. [Crossref]

17. Dranoff G, Jaffee E, Lazenby A, Golumbek P, Levitsky H, et al (1993) Vaccination with irradiated tumor cells engineered to secrete murine granulocyte-macrophage colonystimulating factor stimulates potent, specific and long-lasting anti-tumor immunity. Proc Nat Acad Sci USA 90: 3539-3543. [Crossref]

18. Connor J, Bannerji R, Saito S, Heston W, Fair W, et al. (1993) Regression of bladder tumors in mice treated with interleukin 2 gene-modified tumor cells. J Exp Med 177: 1127-1134. [Crossref]

19. Cavallo F, Pierro FD, Giovarelli M, Gulino A, Vacca A, et al. (1993) Protective and curative potential of vaccination with interleukin-2-gene-transfected cells from a spontaneous mouse mammary adenocarcinoma. Cancer Res 53: 5067-5070. [Crossref]

20. Tahara H, Zeh HJ, Storkus WJ, Pappo I, Watkins SC (1994) Fibroblasts genetically engineered to secrete interleukin 12 can suppress tumor growth and induce antitumor immunity to a murine melanoma in vivo. Cancer Res 54: 182-189. [Crossref]

21. Yu JS, Wei MX, Chiocca EA, Martuza RL, Tepper RI (1993) Treatment of glioma by engineered interleukin 4-secreting cells. Cancer Res 53: 3125-3128. [Crossref]

22. Natsume A, Mizuno M, Ryuke Y, Yoshida J (1999) Antitumor effect and cellular immunity activation by murine interferon-beta gene transfer against intracerebral glioma in mouse. Gene Ther 6: 1626-1633. [Crossref]

23. Liu Y, Ehtesham M, Samoto K, Wheeler CJ, Thompson RC, et al. (2002) In situ adenoviral interleukin 12 gene transfer confers potent and long-lasting cytotoxic immunity in glioma. Cancer Gene Ther 9: 9-15. [Crossref]

24. Sampson JH, Archer GE, Mitchell DA, Heimberger AB, Bigner DD (2008) Tumorspecific immunotherapy targeting the EGFRvIII mutation in patients with malignant glioma. Semin Immunol 20: 267-275. [Crossref]

25. Li G, Mitra S, Wong AJ (2010) The epidermal growth factor variant III peptide vaccine for treatment of malignant gliomas. Neurosurg Clin N Am 21: 87-93. [Crossref]

26. Zhang C, Burger MC, Jennewein L, Genßler S, Schönfeld K, et al. (2015) ErbB2/ HER2-Specific NK Cells for Targeted Therapy of Glioblastoma. J Natl Cancer Inst 108. [Crossref]

27. Kindy MS, Yu J, Zhu H, Smith MT, Gattoni-Celli S (2016) A therapeutic cancer vaccine against G1261 murine glioma. Journal of Translational Medicine 14. [Crossref]

28. Desai R, Suryadevara CM (2016) Emerging immunotherapies for glioblastoma. Expert Opin Emerg Drugs 21: 133-145. [Crossref]

29. Roth P, Preusser M, Weller M (2016) Immunotherapy of Brain Cancer. Oncol Res Treat 39: 326-334. [Crossref]

30. Neagu MR, Reardon DA (2015) An Update on the Role of Immunotherapy and Vaccine Strategies for Primary Brain Tumors. Curr Treat Options Oncol 16: 54. [Crossref]

Copyright: (C)2016 Lichtor T. This is an open-access article distributed under the terms of the Creative Commons Attribution License, which permits unrestricted use, distribution, and reproduction in any medium, provided the original author and source are credited. 